\title{
Urgences
}

\section{Amante et moi}

\section{Normand de Bellefeuille}

Numéro 33, octobre 1991

Poésies parallèles : France - Québec

URI : https://id.erudit.org/iderudit/025666ar

DOI : https://doi.org/10.7202/025666ar

Aller au sommaire du numéro

Éditeur(s)

Urgences

ISSN

0226-9554 (imprimé)

1927-3924 (numérique)

Découvrir la revue

Citer ce document

de Bellefeuille, N. (1991). Amante et moi. Urgences, (33).

https://doi.org/10.7202/025666ar d'utilisation que vous pouvez consulter en ligne.

https://apropos.erudit.org/fr/usagers/politique-dutilisation/ 


\section{Amante et moi}

Normand de Bellefeuille

1.

Mille boîtes retournées dans mon corps

c'est ce qu'a causé l'amante

au retour

je n'ai jamais retrouvé ma rue

le coeur ni ses logements 
58

2.

Le ciel qui est le vent par-dessous

et le sperme, froid, selon les circonstances

cette précision de la douleur

c'est au contraire

le ciel qui est le vent par-dessous

et quelques couteaux aux chevilles de l'amante

car s'il n'y a plus de chats cette année-là

interminables sont alors

ses saisons 
3.

Ce qu'ose l'amante avec les mains: un récit davantage le pressentiment des océans et si je sais qu'il fait nuit je ne juge pas par la lumière plutôt l'ongle plutôt le sang, pâle jusque sous les seins 
60

4.

Car l'amante est fervente une feinte avec les reins souriant quatre mouillures

dont une, imprévisible, aux épaules confondante puis trois aux paupières que l'on croirait être des organes tant l'amante est fervente tant elle coule et, rare, elle inonde 
5.

Amante et moi et l'abominable

le jeune assaut de l'amante puis l'assaut de l'abominable et que le coeur chaque fois contre l'assaut de l'amante et de l'abominable je nous imagine donc un jour, amante et moi au monde proche qui rend vivant 